\title{
Morphotypes of chromosome sets and pathways of karyotype evolution of parasitic Hymenoptera
}

\author{
Морфологические типы хромосомных наборов и направления \\ эволюџии кариотипа паразитических перепончатокрылых \\ (Hymenoptera)
}

\author{
V.E. Gokhman \\ B.E. Гохман
}

Botanical Garden, Moscow State University, Moscow 119991, Russia. E-mail: gokhman@bg.msu.ru Ботанический сад Московского государственного университета, Москва 119991, Россия.

KEY WORDS: chromosomes, karyotype evolution, morphotypes, parasitic Hymenoptera.

КЛЮЧЕВЫЕ СЛОВА: хромосомЫ, эволюция кариотипа, морфологические типы, паразитические перепончатокрылые.

ABSTRACT. Chromosomal diversity of parasitic Hymenoptera has been analyzed with the help of the logical possibility space approach. Using three parameters (haploid chromosome number, length ratios of chromosomes within the haploid set, and the degree of karyotypic "metacentricity"), 18 classes, or morphological types, of chromosome sets have been delimited, of which only 13 contain at least one karyotype. Possible major pathways of karyotypic transformation in parasitic wasps have been outlined.

РЕЗЮМЕ. Хромосомное разнообразие паразитических Hymenoptera проанализировано с помощью подхода, предусматривающего создание пространства логических возможностей. С использованием трех параметров (гаплоидное число хромосом, соотношение длин хромосом в гаплоидном наборе и степень «метацентричности» кариотипа) установлено 18 классов (морфологических типов) хромосомных наборов, из которых только 13 включают хотя бы один кариотип. Определены основные предполагаемые направления преобразований кариотипа паразитических перепончатокрылых.

\section{Introduction}

Parasitic Hymenoptera belong to the very large, taxonomically complicated and economically important group of insects [Rasnitsyn, 1980]. Nevertheless, the detailed picture of karyotype evolution of parasitic wasps is far from being complete, although a few successful attempts of its reconstruction have been made (see Gokhman, 2009). Moreover, research of that kind usually requires a detailed chromosomal study of a certain group, but comparatively few karyotypes of parasitic Hymenoptera have been studied to that extent up to now, apart from aculeate Hymenoptera, especial- ly ants [Imai et al., 1988; Hoshiba, Imai, 1993]. Furthermore, karyotypes, or rather karyomes (term introduced by Smirnov [1991]), usually evolve as holistic objects [Lukhtanov, 1999] (see also Rasnitsyn, 1987), and construction of the so-called chromosomal alteration networks [Imai, 1991, 1993], an apparent tool proposed for analysis of karyotype evolution in many groups of living organisms including Hymenoptera, is probably unable to describe this process in an adequate manner. The main aim of the present paper is therefore a thorough analysis of the major morphotypes and pathways of karyotypic transformation in parasitic Hymenoptera.

\section{Materaial and methods}

To cover the whole range of karyotypic variation in parasitic wasps, their chromosome sets have been analyzed by means of the technique that is widely used in evolutionary morphology, namely, by delimitation of the so-called logical possibility space (see Meyen, 1975). To adequately describe it, three main parameters have been selected to characterize more or less substantial groups of parasitic Hymenoptera: (a) haploid chromosome number ( $\mathrm{n}=3$ to 7,8 to 13 and 14 to 23); (b) length ratios of chromosomes within the haploid set (one or two chromosomes are not less than 1.5 times shorter/longer than the others, or they more or less gradually decrease in size; if chromosomes are obviously uneven by size in any other way, those karyotypes are conditionally included into the latter class); (c) degree of karyotypic "metacentricity" [not less than one-half of all chromosomes are metacentric in a broad sense (including submetacentrics), or acrocentrics (again in a broad sense, including subtelocentrics) predominate within the given karyotype]. Karyotypic data from Gokhman [2009] and a number of recent papers [Gokh- 
man, Gumovsky, 2009; Gokhman, 2010b; Gokhman et al., 2010] together with a few unpublished observations made by the author were used in the analysis; however, information on chromosome sets of certain groups was also taken from a few extra papers [Dreyfus, Breuer, 1944; Hung, 1982; Sanderson, 1988; Hoshiba, Imai, 1993; Abe, 1998; Baldanza et al., 1999; Fusu, 2008]. Using this technique, I have focused on rearrangements that cause substantial changes between certain types of chromosome sets of parasitic wasps. "Within-type" rearrangements are therefore not considered in the present paper, although they may well be responsible for additional karyotypic diversity (see for details Gokhman, 2009). The diversity of morphotypes of chromosome sets within all karyotypically studied superfamilies of parasitic Hymenoptera has been analyzed using corresponding phylogenetic reconstructions (taken from Gokhman [2009] and a few other sources) to reveal main transformation pathways of karyotype evolution in the group studied. The principal phylogeny of the parasitic Hymenoptera used in the present paper is based on the study by Ronquist et al. [1999], which, in turn, is a computerized reanalysis of the dataset presented in the pioneering work by Rasnitsyn [1988]. In the end, possible mechanisms of the above mentioned transformations have been suggested.

\section{Results and discussion}

\section{Morphotypes of chromosome sets of parasitic Hymenoptera}

Eighteen possible classes (morphological types) of chromosome sets of parasitic wasps have been delimited. General distribution of those morphotypes by superfamily is listed in the Table. This information is also given below in more detail.

(1) Ichneumonoidea: Ichneumonidae: Ophioniformes (Mesochorinae): Mesochorus sp.; Braconidae: Aphidius matricariae Haliday, 1834 (Aphidiinae) and most Cheloninae. Cynipoidea: Cynipidae: Andricus mukaigawae (Mukaigawa, 1913). Chalcidoidea: many species of the families Eulophidae, Torymidae, Eupelmidae and some other groups.

(2) Ichneumonoidea: Ichneumonidae: Ichneumoniformes (Ichneumoninae): Dirophanes fulvitarsis (Wesmael, 1845) and Vulgichneumon saturatorius (Linnaeus, 1758); Braconidae (Meteorinae): Meteorus versicolor (Wesmael, 1835). Chalcidoidea: Mymaridae: Anaphes listronoti Huber, 1997.

(3) Ichneumonoidea: Ichneumonidae: Ichneumoniformes (Ichneumoninae): Virgichneumon digrammus (Gravenhorst, 1820).

(4) - (6). No parasitic wasps having karyotypes of that kind are currently known.

(7) Ichneumonoidea: Ichneumonidae: Ophioniformes (Tryphoninae): Netelia latungula (Thomson, 1888); Braconidae: Charmon cruentatus Haliday, 1833 (Charmontinae) and a few Aphidiinae. Cynipoidea: Cynipidae: Andricus kashiwaphilus Abe, 1998. Chalci- doidea: many species of the families Chalcididae, Trichogrammatidae and some other groups.

(8) Ichneumonoidea: Ichneumonidae: a few Pimpliformes, most Ichneumoniformes and a number of Ophioniformes; Braconidae: species of the genus Bassus Fabricius, 1804 (Agathidinae) and a few other groups. Diaprioidea: Diapriidae: all karyotypically known species. Cynipoidea: Cynipidae: species of the genus Diplolepis Geoffroy, 1762; Figitidae: a few species. Platygastroidea: Scelionidae: Telenomus fariai Costa Lima, 1927. Ceraphronoidea: Megaspilidae: Dendrocerus carpenteri (Curtis, 1829). Chalcidoidea: Mymaridae: Anaphes iole Girault, 1911; Aphelinidae: a few species; Eurytomidae: a few species; Eulophidae: Elachertus sp.

(9) Evanioidea: Gasteruptiidae: Gasteruption jaculator (Linnaeus, 1758). Ichneumonoidea: Ichneumonidae: most Pimpliformes and a few Ichneumoniformes; Braconidae: a number of species mostly belonging to the cyclostome group of subfamilies (Doryctinae, Opiinae, Alysiinae etc.).

(10) No parasitic wasps having chromosome sets of that kind are currently known.

(11) Ichneumonoidea: Ichneumonidae: many Ophioniformes and a few Ichneumoniformes; Braconidae: a few species, e.g. Alysia manducator (Panzer, 1799) (Alysiinae). Cynipoidea: Cynipidae: most species. Chalcidoidea: Encyrtidae: a number of species; Eurytomidae: a number of species; Aphelinidae: some species of the subfamily Coccophaginae.

(12) Ichneumonoidea: Ichneumonidae: a few Pimpliformes (Orthocentrinae) and Ichneumoniformes (Cryptinae and Ichneumoninae).

(13) Chalcidoidea: Aphelinidae: a few species of the genera Encarsia Förster, 1878 and Aphelinus Dalman, 1820.

(14) Ichneumonoidea: Ichneumonidae: a few Ophioniformes and Ichneumoniformes (Ichneumoninae).

(15) No parasitic wasps having karyotypes of that kind are currently known.

(16) Chalcidoidea: Aphelinidae: Encarsia tricolor Förster, 1878; Eupelmidae: Eupelmus linearis Förster, 1860.

(17) Ichneumonoidea: Ichneumonidae: Ichneumoniformes: a few Ichneumoninae. Cynipoidea: Figitidae: Ganaspis xanthopoda (Ashmead, 1896) and Leptopilina boulardi (Barbotin, Carton et Kellner-Pillault, 1979). Chalcidoidea: Eupelmidae: Arachnophaga picardi (Bernard, 1936); Encyrtidae: Ageniaspis fuscicollis (Dalman, 1820).

(18) Evanioidea: Gasteruptiidae: Gasteruption assectator (Linnaeus, 1758). Ichneumonoidea: Ichneumonidae: Ophioniformes (Orthopelmatinae): Orthopelma mediator (Thunberg, 1824).

\section{Main pathways of karyotype evolution of para- sitic Hymenoptera}

It is difficult at present to precisely identify the ancestral karyotype for the parasitic Hymenoptera. Spe- 
Table. Distribution of the morphological types of chromosome sets of parasitic wasps by superfamilies. Таблица. Распределение морфологических типов хромосомных наборов паразитических перепончатокрылых по надсемействам.

\begin{tabular}{|c|c|c|c|c|}
\hline \multirow{2}{*}{$\begin{array}{l}\text { Size differentiation } \\
\text { of chromosomes }\end{array}$} & \multirow[t]{2}{*}{ M:A } & \multicolumn{3}{|c|}{ Haploid chromosome number (n) } \\
\hline & & $3-7$ & $8-13$ & $14-23$ \\
\hline \multirow[t]{2}{*}{$\begin{array}{l}\text { One or two } \\
\text { chromosomes } \\
\text { shorter than the } \\
\text { others }\end{array}$} & $\geq 1$ & $\begin{array}{l}\text { (1) } \\
\text { Ichneumonoidea-5 } \\
\text { Cynipoidea-1 } \\
\text { Chalcidoidea-31 }\end{array}$ & $\begin{array}{l}\text { (2) } \\
\text { Ichneumonoidea-3 } \\
\text { Chalcidoidea-1 }\end{array}$ & $\begin{array}{l}\text { (3) } \\
\text { Ichneumonoidea-1 }\end{array}$ \\
\hline & $<1$ & (4) & $(5)$ & $(6)$ \\
\hline \multirow[t]{2}{*}{$\begin{array}{l}\text { All chromosomes } \\
\text { more or less } \\
\text { gradually decrease } \\
\text { in size }\end{array}$} & $\geq 1$ & $\begin{array}{l}\text { (7) } \\
\text { Ichneumonoidea-6 } \\
\text { Cynipoidea-1 } \\
\text { Chalcidoidea-34 }\end{array}$ & $\begin{array}{l}(8) \\
\text { Ichneumonoidea-64 } \\
\text { Diaprioidea-2 } \\
\text { Cynipoidea-5 } \\
\text { Platygastroidea-1 } \\
\text { Ceraphronoidea-1 } \\
\text { Chalcidoidea-6 }\end{array}$ & $\begin{array}{l}\text { (9) } \\
\text { Evanioidea-1 } \\
\text { Ichneumonoidea-18 }\end{array}$ \\
\hline & $<1$ & $(10)$ & $\begin{array}{l}\text { (11) } \\
\text { Ichneumonoidea-10 } \\
\text { Cynipoidea-6 } \\
\text { Chalcidoidea-12 }\end{array}$ & $\begin{array}{l}\text { (12) } \\
\text { Ichneumonoidea-10 }\end{array}$ \\
\hline \multirow{2}{*}{$\begin{array}{l}\text { One or two } \\
\text { chromosomes } \\
\text { longer than the } \\
\text { others }\end{array}$} & $\geq 1$ & $\begin{array}{l}(13) \\
\text { Chalcidoidea-5 }\end{array}$ & $\begin{array}{l}\text { (14) } \\
\text { Ichneumonoidea-4 }\end{array}$ & $(15)$ \\
\hline & $<1$ & $\begin{array}{l}\text { (16) } \\
\text { Chalcidoidea-2 }\end{array}$ & $\begin{array}{l}(17) \\
\text { Ichneumonoidea-2 } \\
\text { Cynipoidea-2 } \\
\text { Chalcidoidea-2 }\end{array}$ & $\begin{array}{l}(18) \\
\text { Evanioidea-1 } \\
\text { Ichneumonoidea-1 }\end{array}$ \\
\hline
\end{tabular}

Remarks. M : A — ratio of metacentrics (M) to acrocentrics (A) in a given chromosome set. Amounts of karyotypically studied species with certain morphotypes of chromosome sets are given for every superfamily.

Примечания. М : А - соотношение метацентриков (M) и акроцентриков (А) в том или ином хромосомном наборе. Количество кариологически изученных видов с данным морфологическим типом хромосомных наборов дано для каждого надсемейства.

cifically, in the superfamily Evanioidea that is considered the most basal superfamily of parasitic wasps with studied chromosome sets (Fig. 1, see also Fig. 5.5 in [Gokhman, 2009]), karyotypes of only two species of the genus Gasteruption Latreille, 1776 (Gasteruptiidae) have been examined. In Gasteruption jaculator, $\mathrm{n}=16$, the ratio of metacentrics to acrocentrics is roughly $1: 1$, and all chromosomes more or less gradually decrease in size. However, in G. assectator $\mathrm{n}=14$ and most chromosomes are acrocentric, although two metacentric chromosomes are substantially longer than the others. The latter karyotypic feature probably indicates two chromosomal fusions that have occurred in the karyotype of $G$. assectator, and therefore the ancestral chromosome set of the Evanioidea (and probably of the parasitic Hymenoptera in general) could have the $n$ value about 16 and a substantial proportion of acrocentrics. Moreover, if chromosome sets of putative ancestral groups within the suborder Symphyta are concerned [Westendorff, 2006; Gokhman, 2010c], higher chromosome numbers in this group are usually associated with higher proportions of acrocentric chromosomes (e.g. in the Xyeloidea, Pamphilioidea and certain Cephoidea), and therefore the ancestral karyotype of parasitic Hymenoptera might well have this feature, i.e. its morphological type can be classified as (12), although I have previously hypothesized that metacen- trics could prevail in this chromosome set (i.e. it could refer to morphotype (9) [Gokhman, 2009]).

Morphological types of chromosome sets of the superfamily Ichneumonoidea are very diverse, and therefore the reconstruction of karyotype evolution of this group that is given below should be considered as provisional. Specifically, eleven morphotypes have been found in the families Ichneumonidae and Braconidae. Among those, morphological types (9) and (12), i.e. karyotypes with $\mathrm{n}=14$ and more, predominate in less advanced groups of the above mentioned families, i.e. in the Pimpliformes and Ichneumoniformes (Ichneumonidae) as well as in the cyclostome group of families (Braconidae). At present, I would suggest that the ancestral karyotype, at least for the Ichneumonidae, is (12). This morphotype is retained in a few Orthocentrinae (Pimpliformes), Cryptinae and Ichneumoninae (Ichneumoniformes), although many other species of those groups as well as most cyclostome Braconidae have metacentric-rich karyotypes, i.e. those of morphological type (9). In addition to the above mentioned transformation from (12) to (9), further transition from (9) to (8) can be observed in the tribe Polysphinctini (Pimplinae) with $n=8-13$. In the Ichneumoniformes, a similar change has probably resulted in the origin of chromosome sets of certain Cryptinae, e.g. Aptesis gravipes (Gravenhorst, 1829), and most Ichneumoni- 


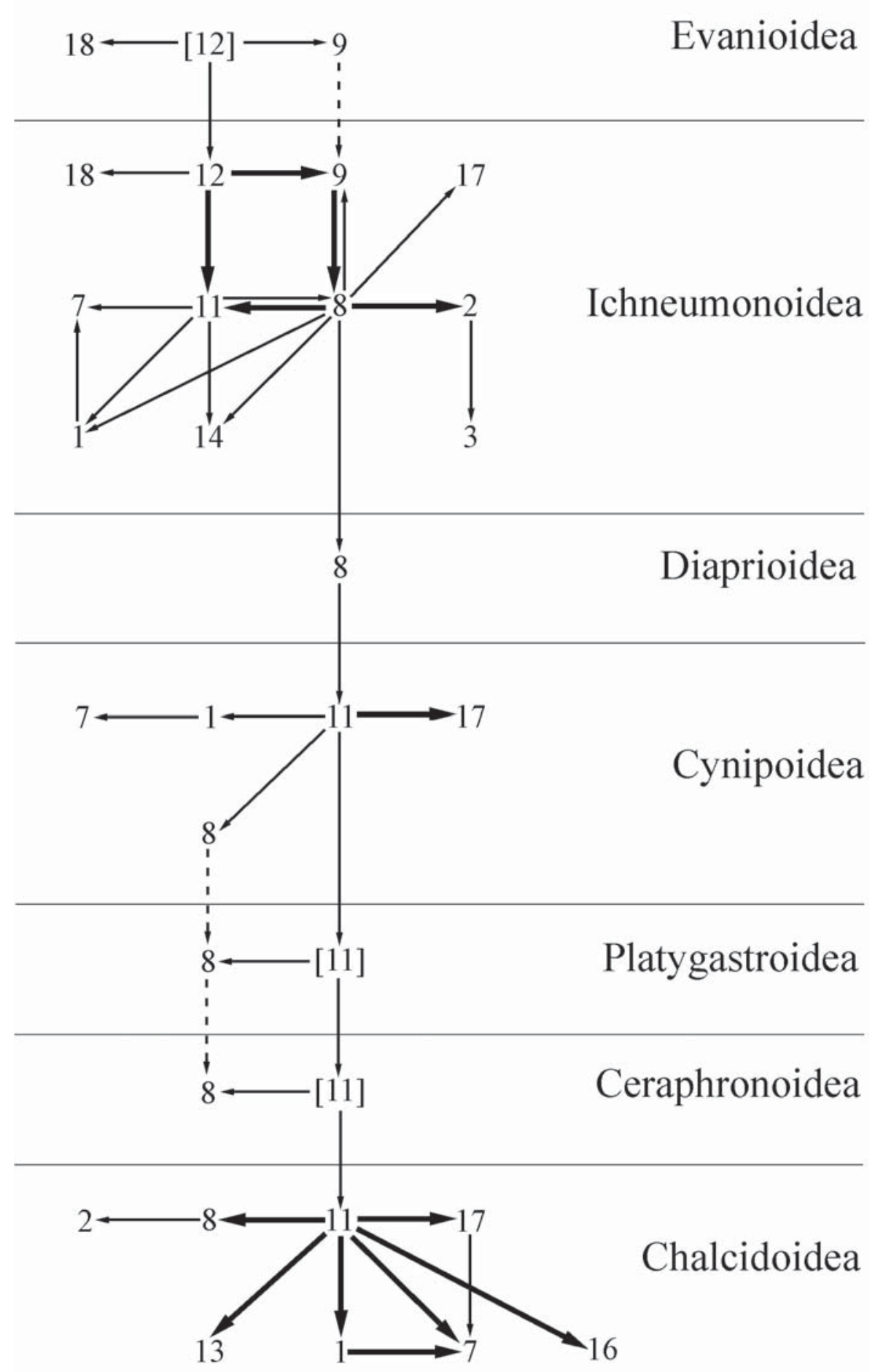

Fig. 1. Evolutionary transformations of morphological types of chromosome sets within various superfamilies of parasitic Hymenoptera. Reconstructed ancestral morphotypes are given in brackets. Plain arrows indicate transformations that are unique at the superfamily level, thick arrows indicate independent multiple transformations, and dashed arrows indicate possible alternative pathways of karyotype evolution.

Рис. 1. Эволюционные преобразования морфологических типов хромосомных наборов в пределах различных надсемейств паразитических Нуmenoptera. Реконструированные предковые морфологические типы приведены в квадратных скобках. Обычные стрелки обозначают преобразования, уникальные на уровне надсемейства, утолщенные стрелки - независимые неоднократные преобразования, а пунктирные стрелки — возможные альтернативные пути эволюции кариотипа. 
nae. Moreover, a transition from (12) to (11) is supposed to form the karyotype of Mesostenus gracilis Cresson, 1864 (Cryptinae). In the Ichneumoninae, one of the above mentioned morphotypes, i.e. (8), is believed to be an ancestral one for the subfamily. From this starting point, a number of transitions took place [to (2) in Dirophanes fulvitarsis and Vulgichneumon saturatorius and further to (3) in Virgichneumon digrammus; to (9) in Chasmias motatorius (Fabricius, $1775)$; to (11) in certain species of the subtribe Cratichneumonina; to (14) in Eurylabus torvus Wesmael, 1845 and to (17) in Cratichneumon fabricator (Fabricius, 1793)]. In the Ophioniformes, the only studied species of Orthopelma Taschenberg, 1875 (the basal genus that is sometimes included in its own group, Orthopelmatiformes) has the chromosome set of morphotype (18). This might indicate that the ancestral karyotype of the Ophioniformes is also of morphological type (12), and the chromosome set of Orthopelma has originated from the previous one through centric fusions. Many other Ophioniformes have karyotypes with decreased chromosome numbers, i.e. those of morphotype (11) and sometimes (8); the latter chromosome sets seem to be derived in this particular case. Moreover, process of pairwise centric fusions of the former chromosome sets could result in the origin of metacentric-rich, low-numbered karyotypes in this group. For example, Hyposoter sp. (Campopleginae) has a diploid chromosome set of twelve pairs of acrocentrics that very gradually decrease in size. On the contrary, chromosome number is twice less in Netelia latungula [morphotype (7)] with six pairs of large metacentrics, thus suggesting the origin of the latter karyotype by pairwise centric fusions. Chromosome sets of Campoplex sp. [morphotype (14)] and Mesochorus sp. [morphotype (1)] are also likely to have similar origins, although at least some of them might represent intermediate stages of the above mentioned process. Patterns of karyotype evolution in the family Braconidae are probably analogous to those of the Ichneumonidae. In the former group, there is also a clear trend towards the emergence of specialized chromosome sets of morphotypes (7) (e.g. in Charmon cruentatus) and (1) (e.g. in most Cheloninae) from less advanced ones, i.e. (8), (9), and (11), although it is impossible at present to reconstruct the above mentioned patterns in detail.

In the superfamily Diaprioidea, only a few species of the family Diapriidae have been studied. Karyotypes of all parasitic wasps of this group can be classified within morphological type (8), including Ismarus flavicornis (Thomson, 1859) that belongs to the genus which is generally considered as relatively basal within the family.

Chromosome sets that belong to morphological types (8) and (11) prevail in the superfamily Cynipoidea. However, according to the phylogenetic reconstruction provided by Ronquist [1999], the family Cynipidae is the most basal group with known karyotypes within the Cynipoidea. Since acrocentrics predominate within chromosome sets of the Cynipidae, morphotype (11) could be considered as an ancestral one for the whole superfamily. Chromosome sets of morphological types (8), (1), (7) and (17) are therefore derived from the ancestral character state.

Chromosomal morphology of the only species of the superfamily Platygastroidea, namely, Telenomus fariai (Scelionidae) has been studied up to now [Dreyfus, Breuer, 1944]. According to these results, its karyotype formally belongs to morphological type (8). However, a considerable proportion of acrocentrics within the chromosome set may well indicate that the real ancestral karyotype for the superfamily could belong to morphotype (11). Although the possibility that the above mentioned karyotype could be metacentric-rich cannot be excluded at present, the proposed hypothesis seems more plausible, especially if compared to ancestral character states that are suggested for the Cynipoidea and Chalcidoidea (see below).

The only karyotypically studied species of the superfamily Ceraphronoidea, Dendrocerus carpenteri (Megaspilidae), demonstrates the chromosome set of morphotype (8). Analogously to the Platygastroidea, however, the ancestral character state in the superfamily is suggested to be (11).

In the superfamily Chalcidoidea, the family Mymaridae is considered the most basal group (see e.g. [Gokhman, Gumovsky, 2009]). However, karyotypes of only two species of the genus Anaphes Haliday, 1833 have been studied up to now within the whole family. Metacentrics prevail in both species, but the genus itself is far from being basal within Mymaridae [Gokhman, Gumovsky, 2009], and therefore the ratio of metacentrics to acrocentrics will probably differ in other Mymaridae. In addition, acrocentrics predominate in a number of less advanced groups of the families Aphelinidae (subfamily Coccophaginae), Eurytomidae and Encyrtidae, and therefore the chromosome set of morphotype (11) is considered as an ancestral one for the superfamily. Several morphological types of chromosome sets are likely to have originated from the latter one. Specifically, certain Aphelinidae, e.g. Coccophagus lycimnia (Walker, 1839) and Eurytomidae, e.g. Sycophila biguttata (Swederus, 1795) have karyotypes of morphological type (8). Some other Aphelinidae, however, have metacentric-rich chromosome sets with one or two chromosomes that are substantially longer than the others, i.e. of morphological type (13). Moreover, karyotype of Encarsia tricolor that also belongs to the Aphelinidae, together with Eupelmus linearis (Eupelmidae), differs from previous ones by being acrocentric-rich, i.e. it falls into morphological type (16). Chromosome sets of another morphotype, (17), have been found in Ageniaspis fuscicollis (Encyrtidae) as well as in Arachnophaga picardi (Eupelmidae). In addition, many species of the family Eulophidae as well as Torymidae together with a few related families, certain Eupelmidae and Eurytoma serratulae (Fabricius, 1798) (Eurytomidae) have karyo- 
types of morphological type (1). Finally, morphotype (7) predominates in many "low-numbered" groups of chalcid wasps (e.g. Pteromalidae and Chalcididae), although it also occurs in a few species of the so-called "high-numbered" families, e.g. in Eurytoma compressa (Fabricius, 1794) (Eurytomidae) and Metaphycus stanleyi Compere, 1940 (Encyrtidae).

It is also interesting to discuss possible reasons for absence of certain morphotypes of chromosome sets. For example, karyotypes with lower chromosome numbers and the prevalence of acrocentrics that gradually decrease in size are unknown in parasitic wasps. This pattern could be explained by the fact that acrocentric chromosomes are prone to Robertsonian fusions that result in appearance of large biarmed elements within low-numbered karyotypes. In turn, very short chromosomes can be detected only within the latter chromosome sets with the prevalence of metacentrics, probably also because smaller acrocentrics could easily undergo centric fusions with the larger ones. On the contrary, longer chromosomes can be found in a few highnumbered karyotypes only if they are acrocentric-rich because this situation probably reflects initial stages of the process of consecutive chromosomal fusions (see below).

Since there are quite a few detailed studies of karyotypic transformations in parasitic wasps (e.g. those involving differential staining or DNA hybridization in situ [Gokhman, 2009, 2010a]), it is difficult at present to give an extensive description of chromosomal rearrangements involved in karyotype evolution of parasitic Hymenoptera. However, the present paper confirms that those rearrangements include centric and tandem chromosomal fusions, pericentric inversions and (in a few cases) chromosomal fissions accompanied by the tandem growth of the constitutive heterochromatin (see for details Gokhman, 2009).

It is obvious that karyotype evolution of parasitic wasps demonstrates many examples of the so-called karyotypic orthoselection [White, 1973] that leads to the origin of similar karyotypes in more or less taxonomically distant groups. Indeed, a number of morphological types of chromosome sets have multiple origins within the best studied families of parasitic wasps. In addition, certain morphotypes are likely to mark similar stages of karyotypic rearrangements. Specifically, if one or two chromosomes (usually metacentric ones) are substantially longer than the others within an acrocentric-rich karyotype, i.e. the chromosome set in question belongs to morphotypes (16), (17), or (18), this may reflect initial stages of the process of consecutive chromosomal fusions [for instance, in Leptopilina boulardi (Figitidae) and Ageniaspis fuscicollis (Encyrtidae)]. On the contrary, presence of one or two smaller chromosomes usually indicates advanced stages of the above process [morphotype (1) that is characteristic e.g. of many Eulophidae], or, alternatively, the result of extensive translocations [morphotype (2), at least in Dirophanes fulvitarsis (Ichneumonidae)]. In the end, low-numbered metacentric-rich chromosome sets of morphotype (7) mark final stages of the process of pairwise chromosomal fusions. The latter morphological type can be found within the Ichneumonoidea, Cynipoidea and Chalcidoidea, although it is certainly more widespread among chalcid wasps.

The present study also reveals the previously underestimated role of centric fusions in karyotype evolution of parasitic wasps. This situation can probably be explained by the fact that many events of that kind have taken place in the superfamily Chalcidoidea, and a number of groups of chalcid wasps (especially those with less derived karyotypes, e.g. certain Eurytomidae and Encyrtidae) were not enough karyotypically studied until recently.

ACKNOWLEDGEMENT. The present study was partly supported by a research grant no. 10-04-01521 from the Russian Foundation for Basic Research.

\section{References}

Abe Y. 1998. Karyotype differences and speciation in the gall wasp Andricus mukaigawae (s. lat.) (Hymenoptera: Cynipidae), with description of the new species A. kashiwaphilus // Entomologica scandinavica. Vol.29. P.131-135.

Baldanza F., Gaudio L., Viggiani G. 1999. Cytotaxonomic studies of Encarsia Foerster (Hymenoptera: Aphelinidae) // Bulletin of Entomological Research. Vol.89. P.209-215.

Dreyfus A., Breuer M.E. 1944. Chromosomes and sex determination in the parasitic hymenopteron Telenomus fariai (Lima) // Genetics. Vol.29. P.75-82.

Fusu L. 2008. The usefulness of chromosomes of parasitic wasps of the subfamily Eupelminae (Hymenoptera: Chalcidoidea: Eupelmidae) for subfamily systematics // European Journal of Entomology. Vol.105. P.823-828.

Gokhman V.E. 2009. Karyotypes of parasitic Hymenoptera. Dordrecht: Springer Science + Business Media B.V. XIII +183 p.

Gokhman V.E. 2010a. [Chromosomal study of parasitic Hymenoptera: results and perspectives] // Trudy Russkogo Entomologicheskogo Obshchestva. Vol.81. No.2. P.6-11 [in Russian].

Gokhman V.E. 2010b. Chromosomes of parasitic wasps of the genus Metaphycus (Hymenoptera: Chalcidoidea: Encyrtidae) // Comparative Cytogenetics. Vol.4. P.21-25.

Gokhman V.E. 2010c. Chromosomes of Xyela julii (Xyelidae) and karyotype evolution in the order Hymenoptera // Melika G. (ed.). Seventh International Congress of Hymenopterists, 2026 June 2010. Programme and Abstracts, List of Participants. Kõszeg, Hungary. P.82.

Gokhman V.E., Gumovsky A.V. 2009. Main trends of karyotype evolution in the superfamily Chalcidoidea (Hymenoptera) // Comparative Cytogenetics. Vol.3. P.63-69.

Gokhman V.E., Mikhailenko A.P., Fursov V.N. 2010. Chromosomes of Blastophaga psenes (Hymenoptera: Agaonidae) // Journal of Hymenoptera Research. Vol.19. No.1. P.187-188.

Hoshiba H., Imai H.T. 1993. Chromosome evolution of bees and wasps (Hymenoptera, Apocrita) on the basis of C-banding pattern analyses // Japanese Journal of Entomology. Vol.61. P.465-492.

Hung A.C.F. 1982. Chromosome and isozyme studies in Trichogramma (Hymenoptera: Trichogrammatidae) // Proceedings of the Entomological Society of Washington. Vol.84. P.791-796.

Imai H.T. 1991. Mutability of constitutive heterochromatin (Cbands) during eukaryotic chromosomal evolution and their cytological meaning // Japanese Journal of Genetics. Vol.66. P.635-661. 
Imai H.T. 1993. A theoretical approach to chromosome banding pattern analysis // Japanese Journal of Genetics. Vol.68. P.97118.

Imai H.T., Taylor R.W., Crosland M.W.J., Crozier R.H. 1988. Modes of spontaneous chromosomal mutation and karyotype evolution in ants with reference to the minimum interaction hypothesis // Japanese Journal of Genetics. Vol.63. P.159185.

Lukhtanov V.A. 1999. [Organization and evolution of karyomes in Lepidoptera]. Autoreferate of D.Sc. Dissertation. St. Petersburg: Zoological Institute, Russian Academy of Sciences. 48 p. [in Russian].

Meyen S.V. 1975. [Problem of directionality of evolution] // Results in Science and Technology. Vertebrate Zoology. Problems of Evolutionary Theory. Vol.7. P.66-117 [in Russian].

Rasnitsyn A.P. 1980. [Origin and evolution of hymenopterous insects]. Moscow. 191 p. [in Russian].

Rasnitsyn A.P. 1987. [Tempos of evolution and the evolutionary theory (hypothesis of the adaptive compromise)] // Tatarinov
L.P., Rasnitsyn A.P. (eds.). Evolution and biocenotic crises. Moscow. P.46-64 [in Russian].

Rasnitsyn A.P. 1988. An outline of evolution of the hymenopterous insects (order Vespida) // Oriental Insects. Vol.22. P.115-145.

Ronquist F. 1999. Phylogeny, classification and evolution of the Cynipoidea // Zoologica Scripta. Vol.28. P.139-164.

Ronquist F., Rasnitsyn A.P., Roy A., Eriksson K., Lindgren M. 1999. Phylogeny of the Hymenoptera: A cladistic reanalysis of Rasnitsyn's (1988) data // Zoologica Scripta. Vol.28. P.13-50.

Sanderson A.R. 1988. Cytological investigation of parthenogenesis in gall wasps (Cynipidae, Hymenoptera) // Genetica. Vol.77. P.189-216.

Smirnov V.G. 1991. [Cytogenetics]. Moscow: Vysshaya Shkola. 247 p. [in Russian].

Westendorff M. 2006. Chromosomes of sawflies (Hymenoptera: Symphyta) - a survey including new data // Blank S.M., Schmidt S., Taeger A. (eds.). Recent sawfly research: synthesis and prospects. Keltern: Goeke \& Evers. P.39-60.

White M.J.D. 1973. Animal cytology and evolution. 3rd edition. Cambridge: Cambridge University Press. 961 p. 